Northwestern University School of Law Northwestern University School of Law Scholarly Commons

Faculty Working Papers

2011

\title{
Strategies of Muslim Family Law Reform
}

Kristen Stilt

Northwestern University School of Law, stilt@law.northwestern.edu

Swathi Gandhavadi

Northwestern University School of Law

\section{Repository Citation}

Stilt, Kristen and Gandhavadi, Swathi, "Strategies of Muslim Family Law Reform" (2011). Faculty Working Papers. Paper 11.

http://scholarlycommons.law.northwestern.edu/facultyworkingpapers/11

This Working Paper is brought to you for free and open access by Northwestern University School of Law Scholarly Commons. It has been accepted for inclusion in Faculty Working Papers by an authorized administrator of Northwestern University School of Law Scholarly Commons. 


\title{
Strategies of Muslim Family Law Reform
}

\author{
Kristen Stilt ${ }^{1}$ and Swathi Gandhavadi ${ }^{2}$
}

Family law in Muslim-majority countries has undergone tremendous change over the past century, and this process continues today with intensity and controversy. In general, this change has been considered one of "reform," defined loosely as the adoption of national laws to modify the rules of Islamic law (fiqh) that had been applicable and predominant in the particular country in an effort to improve the rights of women and children. ${ }^{3}$ Reform efforts have largely focused on placing restrictions on a husband's right to enter into a polygamous marriage; limiting a husband's right to unilaterally declare his wife divorced; extending a mother's right to child custody and to be compensated for it by her ex-husband; raising the minimum age of marriage; expanding a wife's ability to get a divorce at her initiative; requiring a husband to compensate his wife if he arbitrarily divorces her; and limiting a wife's duty of obedience towards her husband. $^{4}$

In some Muslim-majority countries, and Turkey in particular, major modifications to family law have been made by essentially adopting western codes, such that Turkey's family law today resembles that of a European nation. In doing so, Turkish lawmakers, operating in the context of the Turkish form of secularism enshrined in its constitution,

\footnotetext{
${ }^{1}$ Associate Professor, Northwestern University School of Law and Department of History.

2 J.D., Northwestern Law School, 2010.

${ }^{3}$ The term "reform" has been challenged on the grounds that it "insinuates a transition, on the one level, from the pre-modern to the modern, and on the other, from uncivilized to civilized." Hallaq, Shar 'ia, 3 (2009). Since reform is the term used by those engaged in efforts to change personal status law (such as the groups Sisters in Islam, Musawah, others), we use it here. Of course, not all changes in family law in Muslim-majority countries are reformist under our definition.

${ }^{4}$ Welchman, ed., Women's Rights and Islamic Family Law, 4-5 (2004).
} 
did not attempt to justify legal changes as compatible with the classical fiqh. In most Muslim-majority contexts, however, the rules of fiqh remain particularly (and in some jurisdictions uniquely) relevant in the area of family law, and the reform process is usually presented as taking place internally to Islamic law rather than something external to it. The reasons for this internal approach range from faith-based to pragmatic, including the personal beliefs of advocates and lawmakers and concerns over the lack of popular acceptance of a family law that appears to be of western and secular origins. Some women's rights groups are engaging in the internal approach in order to challenge on their own terms those who claim that Islamic law does not allow for expanding the rights of women. ${ }^{5}$

Reformers pursuing this internal method have developed interpretive strategies in order to present changes they desire as Islamically legitimate. In the earliest reforms of Muslim family law in the Middle East, which can be considered to have begun with the 1917 Ottoman Law of Family Rights, three particular strategies were heavily relied upon: exercising preference (takhayyur), patching (talfiq), and constricting the jurisdiction of national courts. In brief, preference involves choosing a more desirable rule (from the perspective of women and children) from a different school of Islamic law than that followed in the particular country or community (or from a minority view from within the school that is followed). Patching is similar, but it involves taking two or more rules or parts of rules and putting them together to form one hybrid rule that, while derived from

\footnotetext{
${ }^{5}$ This is the approach of the Malaysian group Sisters in Islam, for example. Mona Zulficar describes the advocates of a new marriage contract for Egypt (discussed below) as having "adopted a strategy of engagement in the religious discourse based on women's reading of their rights under the principles of the Shari a." Zulficar, "The Islamic Marriage Contract in Egypt," in Quraishi and Vogel, eds., The Islamic Marriage Contract (2008), 242.
} 
fiqh opinions, would not be recognizable (or even permissible) by any one school.

Preference and patching depend on the fact that a diversity of opinion exists within classical Islamic law and in particular among the four Sunni schools of law. The jurisdiction stripping strategy simply removes a topic (for which the Islamic rules produced an unsatisfactory result) from a court's jurisdiction, functionally preventing the judicial application of that rule while not attempting to affect its underlying legitimacy within the corpus of fiqh.

To the extent that the scholarly literature on Muslim family law deals with types of internal strategies (rather than the actual substantive changes), these three particular ones are typically the main or only ones discussed. ${ }^{6}$ Family law reform has been very active in recent years, however, and some advocates have developed creative and innovative ways to continue to push legal change that is presented as coming from within the Islamic legal tradition. This article, drawing mainly on examples from Egypt and Morocco, seeks to identify and examine the breadth of strategies in Sunni Islam that have been used beyond these well-known three. ${ }^{7}$ We are not judging whether each strategy is in any objective sense Islamically compliant, but rather are concerned with studying those reforms that are presented as based on Islamic arguments. ${ }^{8}$ By naming and defining them, we hope to facilitate discussions and research in this area, among academics and those engaged in reform projects alike, in several specific ways.

\footnotetext{
${ }^{6}$ See, for example, Esposito, Women in Muslim Family Law (2001); Ali, "Marriage in Classical Islamic Jurisprudence," in Quraishi and Vogel, eds., The Islamic Marriage Contract, 27 (2008).

${ }^{7}$ As drafts of this article are read by academics and activists, we hope to be made aware of additional strategies (or variations on the ones presented here).

${ }^{8}$ Further, whether any national law can properly be considered to be derived from Islamic law has been challenged. See an-Na im, Islamic Family Law in a Changing World: A Global Resource Book, 19 (2002).
} 
First, we want to encourage empirical studies of the practical impact of reforms. Such studies have been slow in developing, hindered mainly due to lack of access to court records or meaningful statistics. As more of these are undertaken in the future, we suggest that the reform's interpretive strategy should be a variable that is evaluated. Opposition to family law change almost always comes in the form of an attack on its Islamic validity or authenticity, a challenge that the change has gone beyond the bounds of legitimate Islamic legal interpretation. To fully measure a law's impact, including whether members of the population appeal to its use and whether judges are willing to apply it or find reasons to avoid doing so, the Islamic legal justifications for that law must be considered, but this cannot be done without a clear understanding of the current scope of these strategies.

Second, we seek to draw attention to the potential unintended consequences produced by each type of strategy. In each case, the reform is achieved not by simply announcing the desired result, such as a minimum marriage age, for example, but rather by attempting to approximate that desired result to the degree that textual Islamic legal arguments seem to allow. ${ }^{9}$ The strategy used to approach that desired result, however, can itself cause adverse results for the very community that was intended to be helped by the reform. This phenomenon is particularly true with the limitation of judicial jurisdiction strategy, discussed below.

Third, and related to the first two, we intend to contribute to a larger conversation about the benefits and disadvantages of internal approaches, on a case by case basis and as a whole, in comparison with other ways that might be used to achieve legal

\footnotetext{
${ }^{9}$ This approach is also used in the modern field of Islamic finance, where the intended result (a conventional financial product) is approximated through the use of Islamically permissible contracts and transactions.
} 
improvements for women and children. Such approaches might include non-textual arguments derived from Islamic law (such as an appeal to public welfare (ma la $a$ ) generally) or approaches that are guided by principles of human rights or gender equality. These are not mutually exclusive, of course, and by considering strategies comparatively we may find ways in which approaching reforms with a "strong commitment to universal human rights norms, especially the human rights of women and children in the context of family and community" can lead to beneficial results that, in turn, prompt new interpretive approaches to Islamic law in order to support a reform effort with a wide array of arguments. ${ }^{10}$

The first part of this article provides an introduction to Muslim family law, and then the main part is devoted to a discussion of internal reform strategies, beginning with the previously identified preference, patching, and limitation of jurisdiction (with its subpart of conceptual jurisdictional limitation that we identified) for sake of completeness, and then moving to the additional ones. For each, we name and define the strategy and provide examples. In this discussion, the term generic term "legislator" is used to refer in general to the state actors who propose and adopt family law. When more specific actors can be identified, such as the Moroccan king or a women's rights group, they are named more precisely.

\section{Background to Family Law Reform}

Family law reform in the modern period has depended heavily upon, and indeed has taken as its starting point, the rules of Islamic law (fiqh) that the Muslim jurists have developed over past centuries. Beginning in the earliest years of Islam, legal scholars, or

\footnotetext{
${ }^{10}$ An-Na im, Islamic Family Law in a Changing World: A Global Resource Book, xii (2002).
} 
jurists, developed expertise in the Quran, believed to be the direct word of God transmitted to the Prophet Muhammad, and the Prophet's normative practice (sunna), which came to be agreed-upon as the second source. But these two textual sources did not provide answers to every question, and Sunni jurists eventually recognized a process of ijtihad, whereby new rules could be reached from existing ones. The main component of ijtihad was analogical reasoning (qiyas), which resulted in a new rule that was considered merely probable, and no one conclusion precluded the possibility of other, differing conclusions. However, if enough scholars agreed on a conclusion, they could strengthen the authority of an ijtihadi view through consensus (ijma'). Consensus and analogical reasoning form the third and fourth of what are traditionally referred to as the sources of Islamic law, with the Quran and sunna as the first and second. ${ }^{11}$

Over time, jurists clustered around prominent learned individuals and their methodologies and doctrinal results. This led to the development of a madhhab, meaning the path or way followed. This term is usually translated into English as "school"; as an intellectual school, it is a group of jurists loyal to the collective doctrine and the specific methodology worked out by the school and attributed to the school's eponym. ${ }^{12}$ The Sunni schools that garnered enough support over time to survive and flourish are the Hanafi, Maliki, Shafi' $i$, and Hanbali. The strengthening of the schools meant that the doctrinal works of their eminent jurists began to serve as the starting point for legal inquiry. The typical mode of deriving a new rule moved away from ijtihad and toward taqlid, which meant accepting the school's doctrine without a need to confirm its

\footnotetext{
${ }^{11}$ For general introductions to Islamic law, see Hallaq, An Introduction to Islamic Law; ibid., The Origins and Evolution of Islamic Law; ibid., Sharī'a.

${ }^{12}$ Hallaq, The Origins and Evolution of Islamic Law, 152.
} 
correctness from the underlying proof texts. ${ }^{13}$ Even with the continued existence of jurists who were considered capable of ijtihad (and thus called by the related term mujtahid), the schools became so central to legal interpretation that by the tenth century it became possible to speak in terms of the view of a particular school on a particular topic, or the range of views, such as majority and minority, within a school. ${ }^{14}$

Regional areas became associated with particular schools, due to factors that included individual choices and preferences by rulers. For example, the rulers of Egypt from 1250-1517, the Mamluks, were personally Hanafis, but they established a system of four courts so that each Sunni school had its own court, allowing litigants to chose their forum according to their school affiliation. The sultans of the Ottoman Empire were Hanafis, which became the official school of the empire, even though not all Muslims who lived within Ottoman lands were Hanafis and were not required to become so. By adopting an official school, the rulers were not assuming control of the production of the content of the rules, however, which remained in the hands of the jurists. In terms of family law, the jurists developed extensive doctrine in the areas of marriage, divorce, child custody, and inheritance, to identify a few. There are many rules in common among the schools, and the differences do not make one school overall more suitable for a reform agenda than the others, as will be seen below.

\footnotetext{
${ }^{13}$ Jackson, Islamic Law and the State, 79. According to Sherman Jackson, "[B]y the later middle ages the activities of the individual jurist came to be significantly circumscribed by his membership in a particular madhhab. The madhhab, moreover, clearly became the context within which all interpretive activity took place. ... [I]jtihād and taqlīd represent not mutually exclusive linear moments in Muslim history but rather competing hegemonies that stood (and continue to stand) in perpetual competition with each other. ... Ijtiha $\bar{d}$ dominated in the formative period, but taqlīd gains the upper hand from about the 6th/12th century on." Ibid., 77.

${ }^{14}$ Ibid., 77-78. The intent of this brief summary of ijtihād and taqlïd is not to enter into the larger debate of "Was the Gate of Ijtihad Closed?," as Wael Hallaq's 1984 article was titled, or into a discussion of the nuances of each term, but rather simply to indicate that the framework of the four schools, once they were fully formed, extensively controlled juristic activity.
} 
The schools provided structure and stability, and books of legal doctrine, produced by jurists themselves, typically provided school-specific views. Even with the strictures of the schools, these fiqh books still contained pluralities of opinions, such as the school's majority view and minority views. As a result, a judge who followed a particular school of law still had some discretion in determining the rule applicable to the case before him. To limit this discretion and to attempt to provide uniform results, the Ottomans began the practice of forming early versions of law codes (sing. qanun), by compiling the preferred Hanafi rule (which was their official school) on particular topics and requiring judges to use them as the main sources of law. While these efforts at forming codes began earlier, family law was not treated in this manner until the 1917 Ottoman Law of Family Rights, which is considered the first major Muslim family law reform. In Egypt, the first major family law was adopted in 1920, followed by another in 1929, although each of these only dealt with particular issues and neither was a comprehensive code. The typical approach to family law reform, then, involved the issuance of piecemeal laws or in some cases entire family law codes to supplant the previous ability of the judges to determine themselves the applicable law from within (or even beyond) the official school of law's doctrine. The content of those laws and codes, and the strategies used to produce those results, is covered in the next part.

\section{Reform Strategies}

\section{$\underline{\text { A. Exercising Preference (takhayyur) }}$}


One of the earliest strategies used in family law reform has been labeled "the exercise of preference," which takes advantage of the differences among the schools and even the minority views within the schools. Historically, once the schools had internal coherency, a jurist writing fiqh or a judge applying that fiqh to cases before him typically followed the school to which he adhered to the general exclusion of the others. Early reform advocates, and the Egyptian Rashid Rida (d. 1935) in particular, called for a freeing of adherence to particular schools, and developed the idea that rules may be selected from amongst the schools to produce codes that best suited the needs of society at a particular moment in time. The range of potential views to be chosen from using this strategy was limited to existing views, majority or minority, from the schools, however, and did not allow for new rules to be produced from the source texts of the Quran and sunna of the Prophet. ${ }^{15}$

This tactic was used in two early Egyptian personal status laws in 1920 and 1929 and continues to be a common strategy. These two early Egyptian laws dealt with a wife's ability to petition a judge for a divorce, which would be granted without the husband's consent. The generally-agreed upon fiqh rules allowed a husband to unilaterally divorce his wife for any reason, but a wife's ability to get a divorce when her husband did not want to do so was limited to particular reasons that differed from school to school. The Hanafi school, which remains the official school in Egypt for personal status matters, provided very few grounds, such as long-term abandonment, while in the

\footnotetext{
${ }^{15}$ One significant question raised by the use of the internal approach to family law reform is whether the legislator is considered within his or her particular society capable of claiming the right to conduct ijtihad and to return to the original source texts to produce new rules that have no precedence in classical figh. To at least one author, the strategy of exercising preference can be called "selective ijtihad," in contrast to the historical concept of ijtihad, which the author calls "innovative ijtihad." See El Alami, "Law No. 100 of 1985 Amending Certain Provisions of Egypt's Personal Status Law,” 130.
} 
Maliki school, a wife could seek a judicial divorce for abandonment and lack of financial and material support as well as for the broad categories of harm and injury. The Maliki grounds were adopted in Egypt in Law 25 of 1920 and Law 25 of 1929.

Similarly, Morocco, which has officially adopted the Maliki school, used exercising preference in its first family law code, which was promulgated in 1958, and in the new family code of 2004. For example, at the time of the 1958 code, Maliki rules as had been applied in Morocco required a wife to provide her husband with a gift to the household prior to consummation of the marriage. Such gifts were typically paid for out of the marriage gift that the husband had given the wife, essentially eliminating the financial benefit that the wife was supposed to receive through the marriage gift. ${ }^{16}$ The 1958 law adopted the Hanafi rule that insisted that the marriage gift remain the wife's property, which she could dispose of as she pleased, and no longer required a gift in return to her husband.

\section{B. Patching (talfiq)}

Patching is similar to preference and also relies on the assumption that rules of different schools may be selected from to produce an eclectic code, but instead of taking a rule wholesale as in exercising preference, patching involves selecting smaller pieces of rules and fitting them together to make one new rule. There are far less examples of patching than of exercising preference, and to some extent the line between the two is not well defined. One example comes from the 1958 Moroccan family law code, in which reformers addressed the husband's right to unilaterally pronounce his wife divorced. Since such a pronouncement is considered a speech act that has legal effect, a husband

\footnotetext{
${ }^{16}$ Anderson, "Reforms in Family Law in Morocco," 151.
} 
who makes such a statement out of anger, for example, without the intention to actually effectuate a divorce could, depending on the school, find that he had in fact divorced his wife. Reformers wanted to identify circumstances under which the husband's pronouncement was ineffective, resulting in Article 49, which stated that a repudiation pronounced by a man when he is completely intoxicated or uncontrollably or violently angry is not effective, nor is a pronouncement that is made when the man is acting under compulsion. The compulsion exception is a Maliki rule, while the drunkenness exception is not supported by the dominant opinions in the Maliki, Hanafi, or Shafi ${ }^{i}$ i schools but has support from minority views within those schools. The exception for anger comes from the Hanafi school and from individual Maliki and Hanbali jurists. The resulting list as a whole, then, would not be recognized by any one particular school, but is a patchwork of several schools and individual views. ${ }^{17}$

\section{Limitation of Jurisdiction}

The third type of strategy that has been used from the early twentieth century involves preventing the application of a rule of classical fiqh that the legislator has deemed undesirable by removing a factual scenario that would lead to the application of that rule from the decision maker's purview. Typically, this meant stripping judicial jurisdiction to avoid the rule's application. Unlike the previous two, this strategy admits that a desirable rule cannot be found in the existing corpus of fiqh, whether a minority view or even the view of one jurist, to supplant the currently prevailing rule of fiqh. Insofar as it operates to limit judicial jurisdiction, this strategy has been called the

\footnotetext{
${ }^{17}$ Ibid.
} 
"procedural expedient." ${ }^{18}$ We present this tactic here with a clearer name and also add to it the related strategy of limitation of conceptual jurisdiction.

\section{Limitation of Judicial Jurisdiction}

By declaring that courts do not have jurisdiction in certain areas, the legislator prevents the application of fiqh rules deemed unfavorable. The goal is not only to set aside such rules but also to encourage the public to avoid placing themselves in the factual scenarios that would be governed by those rules by removing the possibility of judicial relief.

A good example of this strategy involves the minimum marriage age. The Quran refers to maturity of mind (rushd) as a necessary marital precondition, and jurists elaborated on this concept to determine more precisely that an individual must attain physical maturity (bulugh) in order to marry. The schools of law came to their own conclusions about the minimum age at which physical maturity could be reached, which, for the Hanafi school, was nine years for girls and twelve for boys. Marriages could be contracted earlier, but the actual consummation of the marriage must wait until the parties are physically mature. ${ }^{19}$

Twentieth-century reformers determined that such minimum marriage ages were too low and that girls in particular who married as minors had diminished chances of receiving a proper education. And yet no view within the schools of law, or even by an individual jurist, supported raising minimum ages as high as reformers sought to achieve. Without claiming that the Hanafi (or other fiqh rule) was simply abrogated, something the

\footnotetext{
${ }^{18}$ Anderson, "Law Reform in the Muslim World."

${ }^{19}$ Shaham, “Custom, Islamic Law and Statutory Legislation,” 261.
} 
legislators did not believe they could do without provoking intense opposition and perhaps did not even want to do as a religious matter, Egyptian Law 56 of 1923 removed from the jurisdiction of courts claims arising from marriages if the wife had been under 16 and the husband had been under 18 at the time of the marriage. ${ }^{20}$ The types of such claims were not enumerated in the law, but could have included claims about the existence of the marriage or a wife's petition for maintenance from a non-supporting husband or for judicial divorce. The parties to an "under-age" marriage were thus permanently barred from seeking judicial relief, a result that was eventually seen to be too harsh and even detrimental to the wife, who was supposed to be the main beneficiary of the legislation. Law 78 of 1931 amended Law 56 to omit the phrase "at the time of the marriage," so that the parties only had to be of the specified ages at the time of the judicial claim.

These laws did not affect the underlying religious validity of "under-age" marriages. While notaries were instructed to only register marriages when both parties met the minimum specified ages, registration with a notary was never considered a necessary part of a Muslim marriage; in a two-part process, the parties would marry religiously and also register with the state notary. This strategy did not forbid individuals from marrying below the specified age, but rather it tried to discourage them from doing so by threatening that there would be no judicial remedy for claims relating to the marriage if, initially, they were under-age when the marriage took place or, subsequently,

\footnotetext{
${ }^{20}$ Marriage notaries were prohibited from registering a marriage if one of the parties was under the mentioned ages. A separate issue is how ages are proven to a marriage notary or judge. Some individuals simply fail to keep or obtain their official birth certificates, while others claim that they have lost or never received the required documentation. Under these circumstances, notaries should request medical reports and witness testimony to verify each spouse's age, but doctors and witnesses can bribed for the purpose of providing false corroborating evidence to the notaries.
} 
underage when the claim was made. Women were thus left unprotected by the courts for claims relating to their marriages between the time of the marriage and their sixteenth birthday. Reformers hoped that the threat of the inability to resort to a judge would deter couples - and women and their guardians - from contracting marriages below the specified ages.

\section{Limitation of Conceptual Jurisdiction}

A strategy related to the limitation of judicial jurisdiction removes a topic not from a judge's jurisdiction but rather attempts to convince society at large that a matter is properly outside the scope of Islamic rules of doctrine. A good example comes from the Moroccan laws of kafala, which is the fiqh-based legal process used in Morocco for placing abandoned children in new permanent families. Although kafala often involves physical custody and other attributes of adoption, it is legally distinct from adoption and the child is not treated like a birth child in many important regards. The western conception of adoption (tabanni) is prohibited in classical Islamic law ${ }^{21}$ and in Moroccan law. ${ }^{22}$ Parents who "adopt" a child in the kafala process become their legal guardians but they are not subject to the full range of rights and responsibilities as are biological parents. Kafala children do not inherit from their kafala parents (an issue discussed below) according to Islamic inheritance law, but remain the heirs of their biological parents (which may not have any meaning in practice if the biological parents abandoned the child or are no longer living).

21 Powers, Muhammad is not the Father of any of your Men; Landau-Tasseron, "Adoption, Acknowledgement of Paternity and False Genealogical Claims in Arabian and Islamic Societies," Bulletin of the School of Oriental and African Studies 66 (2003) 169.

22 Bargach, "Study on Abandonment," 8. 
Reformers sought ways to improve the integration of kafala children into their new families, and concluded that the child's different last name was one obstacle. A name is comprised of multiple parts, including the first name, grandfather's name, father's name, and family name. According to Moroccan kafala procedures, during the process, a social worker considers the parents' family name and selects a family name for the kafala child that may be similar to that of the parents but cannot be identical. ${ }^{23}$ Due to a recent change in the regulations, however, once the kafala process is completed, the parents may petition the Ministry of Interior and request that the child receive an identical family name. Allowing for this name change was justified on the grounds that family names are a European custom for which there is no Islamic equivalent. ${ }^{24}$ Conceptually, then, family names are considered to be outside the jurisdiction of Islamic law. The legislators also asserted that making this option available is in the best interests of the child, but apparently this was not a sufficient basis upon which to justify the reform. ${ }^{25}$

\section{Assignment of Power to the Judiciary or Other State Official}

This is the opposite strategy of the previous one, and involves adding powers to a judge's or other official's jurisdiction that previously were left in the hands of individuals. The assumption underlying this strategy is that judges as neutral arbiters will reach better conclusions than individuals, who would presumably act out of sheer self interest, thereby promoting the goals of the reform.

\footnotetext{
${ }^{23}$ Interview with Jamila Jouda, Moroccan Association Ennakhil pour la Femme et l'Enfant, March 20, 2009; Interview with Karima Essebah, official in the Moroccan Ministry of Health, March 23, 2009.

${ }^{24}$ Bargach, "Abandonment," 6; Jouda interview; Essebah interview; Ministry of Justice, "Regulations Implementing the Law of Civil Status," Oct. 9, 2002. The parents are not required to give the child their last name, thus preserving the traditional kafala rule, but insofar as the authorities encourage the parents to do so, this intersects with the "encouraging the permissible" reform strategy (see below).

25 Jouda interview.
} 
This strategy has been used widely in modern polygamy legislation that aims to constrain a man's ability in Islamic law to be married to up to four wives at one time. Few Muslim-majority countries have abolished polygamy as a matter of national law, and most attempt instead to curtail the rights of a husband to enter into a polygamous marriage and to protect the rights of the first wife. Reformers place emphasis on the Quranic verse that requires equitable treatment among the wives: “... then marry from among [other] women such as are lawful to you-[even] two, three or four; but if you have reason to fear that you might not be able to treat them with equal fairness, then [only] one ...."26 The verse seems to speak to the man who is contemplating taking a second wife, and cautions him to consider whether he can provide equally for them. Yet, another Quranic verse suggests that men cannot accomplish this admonition to treat all wives fairly: "And it will not be within your power to treat your wives with equal fairness, however much you may desire it; and so, do not allow yourselves to incline towards one to the exclusion to the other, leaving her in a state, as it were, of having and not having a husband."27

Syrian and Iraqi personal status codes that were promulgated in the 1950's both adopted a notion that reformers had been suggesting since the early 1900's, which is that the polygamy warnings should not merely be binding on the individual man's conscience but should be determined and enforced by courts. ${ }^{28}$ Article 8 of the Iraqi Law 188 of 1959, which was the first family law code for post-independence Iraq, provided that marriage with more than one wife is not permitted without the permission of the judge,

\footnotetext{
${ }^{26}$ Q 4:3 (Muhammad Asad, transl.).

${ }^{27}$ Q 4:129 (Muhammad Asad, transl.).

28 This idea was advanced by Muhammad 'Abdu and Rashid Rida. Anderson, "The Syrian Law of Personal Status," 36; Anderson, “A Law of Personal Status for Iraq,” 542.
} 
and permission will be granted only if two conditions are met: the husband is financially capable of supporting more than one wife, and the polygamous marriage will involve some lawful benefit. ${ }^{29}$ The Syrian approach was similar: a man seeking a polygamous marriage should seek permission from a judge, who can withhold it if the husband is not financially capable of supporting them both. Yet, such a marriage made without the judge's permission is still valid, in deference to the children who might be born form such a union. ${ }^{30}$

Morocco adopted a similar approach, but not until the 2004 code (which is known by its Arabic short form, Mudawwana). ${ }^{31}$ In the preamble, the Moroccan King declared that he would not outlaw polygamy because it is allowed under Islamic law. ${ }^{32}$ The King noted that a motivating factor in regulating, rather than abolishing, polygamy was the concern of "illegitimate polygamy occurring if we prohibit it entirely.",33 Polygamous marriages would be allowed only "under compelling circumstances and stringent restrictions and with the judge's authorization." ${ }^{34}$ A judge must verify that a husband can treat his first wife and children equally to the new wife and must further establish an "exceptional motive" justifying polygamy. ${ }^{35}$ The prospective second wife must receive notice that her future husband is already married and must consent to a polygamous marriage. ${ }^{36}$ The law provides the first wife a cause of action against the husband for any

\footnotetext{
${ }^{29}$ The law further provides that contracting a marriage with more than one wife without judicial approval is punishable by a fine, imprisonment, or both.

${ }^{30}$ Anderson, "The Syrian Law of Personal Status," 36.

${ }^{31}$ While the Moroccan Ministry of Justice had proposed such a rule in preparation of the 1958 code, it was not adopted on the grounds that such restrictions were impracticable given the Moroccan social context.

${ }^{32}$ Mudawwana, preamble para. 4.

${ }^{33}$ Ibid. This suggests that even if polygamy was abolished in national law, the state would not seek to deem polygamous marriages invalid as a matter of religious law.

${ }^{34}$ Ibid.

35 Ibid.

${ }^{36}$ Ibid., preamble para. 4 , art. 46.
} 
harm suffered, including the "harm" caused by her husband taking another wife. ${ }^{37}$

\section{E. Relying Upon a Lesser-Known Text}

This approach differs from patching because it does not depend on the existence of a pre-existing rule of figh conducive to the reform, and indeed assumes that such a rule cannot be found. In this strategy, which has not been very common to date, the reformer goes directly to the sources of Islamic law, the Quran and sunna (which is composed of individual reports of the Prophet, hadith), to identify and put forward as authoritative a text that had not previously been relied upon by the jurists to support the particular view adopted. Without challenging or even commenting upon the previous prevailing fiqh rules, the legislator simply attaches this newly identified source text to the national law as Islamic support. This approach does not necessarily involve a full examination of the source texts to answer a new question, but rather a single text is extracted and juxtaposed alongside the new law to bolster it.

An example of this strategy comes from the Moroccan family law of 2004. In the previous family law code, marriage was defined as a legal contract whereby a man and a woman unite for a common and lasting conjugal life. The code emphasized fidelity, virtue, and the need to procreate within a marriage, which was under the direction of the husband. The 2004 Mudawwana took the position that women should be afforded greater rights and should be viewed as equal partners in their marriages. The Preamble explained that these reform efforts were supported by the hadith of the Prophet Mohammed, "Only

\footnotetext{
${ }^{37}$ Ibid., preamble para. 4.
} 
an honorable person dignifies women, and only a villainous one degrades them." ${ }^{38}$ The Mudawwana presents this verse as evidence that a family should be placed under the joint responsibility of both spouses. ${ }^{39}$ This sentiment is reiterated in Article four, which notes that the purpose of marriage is fidelity, virtue, and the creation of a stable family, which is created by the recognition of marriage as a union where a man and a woman mutually consent to unite in a common and enduring conjugal life. ${ }^{40}$

The Mudawwana presents another source text when discussing a woman's right to enter into marriage. In Maliki law, a woman's guardian must conclude her marriage contract for her, implicitly giving the guardian the ability to control whom she marries. ${ }^{41}$ Preamble two of the Mudawwana cites part of a Quranic verse, “...hinder them not from marrying other men if they have agreed with each other in a fair manner, ${ }^{, 42}$ to support the idea that a woman of marriageable age may exercise her right to marry "according to her choice and interests." ${ }^{43}$ Alternatively, if a woman so desires, she may delegate this responsibility to "her father or a male relative." 44 And yet the full verse begins with the phrase "and when you divorce women, and they have come to the end of their waiting period, hinder them not ...," indicating that the verse is not intended to apply to all women seeking to enter into marriage, nor is it directed to society at large, but rather specifically to men who divorce their wives and then try to prevent them from remarrying.

${ }^{38}$ Mudawwana, preamble 1. This hadith is not found in any of the major hadith collections, but appears in [The Book of Forty Hadith Regarding the Virtues of Mothers of the Faithful]. This hadith has been criticized by a modern scholar as weak and possibly false. Muhammad Nasr al-Din al-Albani, [A Compendium of Weak and Forged Hadiths and their Negative Impact on Society] vol. 2, hadith 735, 241.

${ }^{39}$ Mudawwana, preamble 1 .

${ }^{40}$ Ibid., art 4.

${ }^{41}$ Ali, "Marriage in Classical Islamic Jurisprudence," 14.

${ }^{42}$ Q 2:232 (Muhammad Asad, transl.).

${ }^{43}$ Mudawwana, preamble 2.

${ }^{44}$ Ibid. 
Another example comes from the Mudawwana's efforts to constrain a husband's ability to make a unilateral divorce pronouncement, justified on the basis of the wellknown hadith, "of all the lawful acts, the most hateful to God is divorce."45 To prevent the husband from abusive and arbitrary practices, the women's ability to initiate and receive a divorce is bolstered and the husband's obligations to a divorced wife and the children are strengthened, with the hope that this will deter the husband from hasty and irrational divorce proclamations. For example, the law requires a husband who wants to repudiate his wife to petition the court for authorization. ${ }^{46}$ (The wife has a similar power of repudiation only if she was granted it by her husband in the marriage contract, which is discussed below). The court will then summon the spouses for a reconciliation attempt, ${ }^{47}$ apparently on the presumption that most repudiation petitions come from husbands who want to divorce their wives against their will and that maintaining the marriage would benefit the wife. If reconciliation attempts fail, the court determines a sum of money that covers all of the husband's obligations to the wife and children, and the husband must deposit this amount with the court before the court will authorize the repudiation. ${ }^{48}$ Thus, limits have been placed on the husband's right to repudiate for no cause. Women may also seek a divorce on the basis of the harm caused to her by her husband in a wider range of circumstances than previously allowed. Failure of the husband to respect any condition of the marriage contract is considered to constitute a harm justifying a divorce

\footnotetext{
45 Ibid., preamble clause 6. The hadith can be found in Sunan Abu Dawud, vol. 3, p. 20, hadith 2177-2178. ${ }^{46}$ Mudawwana, art. 79.

${ }^{47}$ Ibid., art. 81.

${ }^{48}$ Ibid., art. 84-87. The sum includes the delayed marriage gift, if applicable; maintenance for the wife's waiting period ( 'idda); and a consolation gift ( $m u t^{\prime} a$ ), which is determined on the basis of the length of the marriage, the financial means of the husband, the reasons for the repudiation, and the husband's degree of fault. The amount due to the dependent children depends on their standard of living and education status. Art. 85
} 
request from the wife. ${ }^{49}$

\section{$\underline{\text { F. Reinterpreting a Source Text }}$}

This strategy involves taking a well-known source text, typically a hadith, and reinterpreting it to provide support for a new national law. Unlike the previous strategy, which advances a source text that had not been relied upon (or even well known or accepted) previously, in this case, the source text for the existing rule is known, and the reformer works directly with that source text to establish a new interpretation of it. A clear use of this strategy comes from Egypt's 2000 family law reforms, and specifically

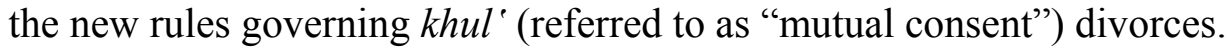

Prior to this law, there were two main ways for a woman to get a divorce from her husband in Egypt. Judicial divorce for harm, which was discussed in the "exercising selection" reform strategy, required the wife to prove that her husband had harmed her in one of the enumerated ways. While Egypt had expanded the list of behavior that constituted harm using the "exercising selection" reform strategy, legislators apparently believed that they had reached the limit on extending the list and did not have any more options to provide to women under the heading of judicial divorce for harm.

The second mechanism open to a woman prior to the 2000 law was divorce by mutual consent, which involved a wife offering something of value to her husband to obtain his consent to the divorce ${ }^{50}$ Typically, the wife returned the marriage gift that the husband had given her and whatever other financial compensation the husband

\footnotetext{
${ }^{49}$ Ibid., art. 99.

${ }^{50}$ Arabi, "The Dawning of the Third Millennium," 3. If a woman had obtained a delegated power of divorce from her husband in the marriage contract, however, she could also divorce herself on his behalf if the conditions mentioned in the marriage contract were met.
} 
demanded. Unlike judicial divorce for harm, the woman could ask her husband for a mutual consent divorce for any reason, including simple incompatibility. As mutual consent divorces existed in Egyptian law, based on Islamic law, the husband still had to consent to the divorce that his wife offered to "purchase" from him; it was seen as requiring an offer from the wife and an acceptance from the husband.

The Egyptian legislature in 2000 added a second kind of mutual consent divorce to national law, in which the court can essentially order the husband to accept the wife's offer provided certain financial conditions are met. The wife begins the process by claiming that she detests her life with her husband, that there is no way their marital life can continue, and that she fears that she will fail to abide by the limits of God because of her hatred for the marital life. After this declaration, judicial arbiters attempt to reconcile the couple. After this time, if the woman insists on the divorce and returns the marriage gift the husband gave to her, the court will grant a divorce, which is considered a final divorce that may not be appealed. ${ }^{51}$

The basis for mutual consent divorce in Islamic law comes from a series of hadiths, each similar but with some differing details. The typical hadith involves a woman named Habiba (or Jamila in some) who approached the Prophet and said that while her husband, Thabit b. Qays al-Ansari, had done nothing wrong, she feared that she would transgress her religion if she remained married to him. The Prophet asked her if she would be willing to return to her husband the garden he gave her as a marriage gift in exchange for receiving the divorce. When she replied in the affirmative, the Prophet

\footnotetext{
${ }^{51}$ Egypt, Law 1 of 2000.
} 
instructed the husband to take what she offered, which he did. ${ }^{52}$

While the hadiths suggest that the husband did not have any choice in the matter and had to accept the return of the marriage gift and grant his wife a divorce, the classical jurists viewed this divorce as truly one of mutual consent, meaning that the husband did not have to accept the wife's offer, in which case no divorce would take place. This position was based in part on a Quranic verse that speaks to the context of a husband repudiating his wife: "And it is not lawful for you to take back anything of what you have ever given to your wives unless both [partners] have cause to fear that the two may not be able to keep within the bounds set by God: hence, if you have cause to fear that the two may not be able to keep within the bounds set by God, there shall be no sin upon either of them for what the wife may give up [to her husband] in order to free herself." $" 53$ The jurists concluded that (1) the Quranic verse presumed that both parties agree on the wife's freeing herself in this manner; (2) the hadith spoke to the same legal process as mentioned in the Quranic verse; and, thus (3) that the husband's consent was required for this type of divorce, leading to the label of "mutual consent" divorce. ${ }^{54}$

The Egyptian legislators returned to the hadiths to find support for the idea that the husband's consent was not necessary. The legislators determined that the Prophet's role as mediator, and perhaps even as the one who instructed the husband to accept the deal, would be played in modern Egypt by a judge, who had the power to declare a mutual consent divorce. While the literal language of the hadith seemed to support the Egyptian view, the fact that the hadith had been interpreted by the jurists to require

${ }^{52}$ Sahih al-Bukhari, vol. 7, hadiths 5273-5277. In one version, the Prophet asked Habiba if she would return the garden, and she said that she would and that she would give in excess of that. In another version, the Prophet told her to give back the garden and something in excess of it.

${ }^{53}$ Q 2:229 (Muhammad Asad, trans.)

${ }^{54}$ See Arabi, "The Dawning of the Third Millennium," 8-16. 
consent, by linking the hadith to the Quranic verse, meant that the Egyptian legislators were in fact basing their views on the reinterpretation of a hadith. ${ }^{55}$

\section{G. Making Lawful Parallel Contracts and Stipulations in Contracts}

This strategy seeks to make lawful the stipulations that parties add themselves to a nominate contract (such as a marriage contract) or to contracts that parties enter into alongside the main contract. ${ }^{56}$ The goal is to allow parties to agree among themselves to prevent (or require) a practice in the context of their own private contract that the legislators are not able to make illegal (or mandatory) under national law. The clearest example of this concerns polygamy, a matter of great concern to reformers. ${ }^{57}$ Since abolishing polygamy in most contexts has been considered beyond their ability, due to entrenched social, cultural, and religious beliefs (and often practices), they sought to give the parties themselves (and wives in particular) the power to enter into agreements with their husbands to accomplish the result that could not be mandated on the national level.

Since side agreements, or stipulations in the main nominate contract, have not always been upheld in courts, this strategy provides assurance to parties that the parallel contracts and stipulations they insert in their contracts will be recognized and enforced. (In some cases, in particular in the adoption context, the parallel contract is actually made

\footnotetext{
${ }^{55}$ Arabi describes Law 1 of 2000 as separating the hadith from the Quranic verse, to add a second option to the pre-existing Egyptian law that requires the husband's consent in a khul' divorce. This new second option is available when the husband does not consent, and the court will force his consent in exchange for the return to him of the marriage gift. Arabi, "The Dawning of the Third Milleniun," 18. Women's rights groups who typically represent poorer women complained that this new provision only benefits wealthy women who are able to pay the husband back for the marriage gift. Welchman, Women's Rights and Islamic Family Law.

${ }^{56}$ Islamic contract law is based on nominate contracts (such as sales, lease, and marriage, which is treated as a contract albeit a special kind) that contain specific types of terms inherent in the particular type of transaction. Parties are generally not permitted to add additional terms to the contract, except in the Hanbali school of law.

${ }^{57}$ Ranging from Rashid Rida to Sisters in Islam, the latter of which have made the abolition of polygamy in Malaysia, legally and practically, one of their main goals.
} 
incumbent upon one party by the state, acting as the counter-party.) The use of stipulations in contracts is itself possible due to the well-established "exercising preference" strategy, since it is mainly the Hanbali school that allows for the enforceability of stipulations, as long as they do not undermine the object of the contract itself. Reformers in jurisdictions that do not follow the Hanbali school have to base their arguments for the permissibility of stipulations on the choice of the Hanbali school to govern them. In turn, the permissibility of parallel contracts and stipulations is a precondition for the next strategy, called "encouraging the permissible," which typically goes one step further and actually tries to convince (or require) parties to use these stipulations or parallel contracts.

In the context of marriage, a woman might attempt to limit her husband's right to marry a second wife by adding such a limitation into the marriage contracts; the violation of this stipulation entitles the woman to a divorce from her husband (and not specific performance of the restriction). While evidence exists that women used such stipulations in Egypt in the Ottoman period and that they were enforced by courts, showing that the Hanafi Otttoman judges were willing to recognize Hanbali law, courts in the new Egyptian state ceased to recognize and enforce them. ${ }^{58}$ Further, some marriage notaries might not have been willing to put the stipulations in the marriage contract on the grounds that it was contrary to Hanafi law.

Some parties as a result entered into a separate contract at the time of the marriage that expressed the anti-polygamy stipulation, out of concern for the possible lack of judicial enforcement of a stipulation in the marriage contract itself. While such parallel

\footnotetext{
${ }^{58}$ Sonbol, "A History of Marriage Contracts in Egypt," in Quraishi and Vogel, eds., The Islamic Marriage Contact, 114.
} 
contracts were typically upheld, reformers believed that it was unlikely that many women would have the courage to ask their fiancés to enter into such a contract. It would also require the parties to write the contract on their own or to consult a lawyer, something beyond the means of most Egyptians. While many iterations of marriage contracts have been proposed or used in Egypt (as discussed in the next strategy), the current Egyptian marriage contract contains a blank space where parties can write in their stipulations, and they will be upheld provided that they do not vitiate the object of the contract itself (stipulating that the parties will not engage in sexual intercourse is an obvious objectionable one since marriage clearly makes this behavior licit). The marriage certificate is filled out by the official marriage notary per the statements given by the parties. This blank space allows women to add in conditions such as that the husband will not take a second wife or that the wife is permitted to finish her university education or work outside of the home. Placing this space on the marriage contract, however, is by no means a guarantee that women will use it or will even know the range of possible stipulations. It also does not help a woman who proposes a stipulation and then is told by her fiancé that it is impermissible and that it will void the entire contract. Building in large part on the enforceability of stipulations and parallel contracts, in the next strategy, reformers actually encourage and promote them.

\section{$\underline{H .}$ Encouraging or Requiring the Permissible}

This strategy recognizes that a gap exists between what is permissible as a matter of Islamic law and what reformers can actually manage to require as state law. 
Reformers try to approximate the benefits of a state law requirement by actively encouraging individuals to take advantage of options they already have. This strategy depends in large part on the permissibility of parallel contracts or stipulations in contracts, but actively promotes them among the population. At one level, this is something like a "know your rights" campaign but goes further in that reformers attempt to require the encouragement as part of national law. Further, in some cases, notably related to inheritance and adoption, "encouraging the permissible" becomes "requiring the permissible," which essentially means recognizing a possibility under Islamic law and then coercing an individual into adopting that possible action.

A good example of this strategy in the marriage contract context is a campaign in Egypt that has not yet been successful. While women may add stipulations in their contract, as discussed above, reformers and women's rights activists in particular concluded that many women were not aware of the general permissibility of stipulations as a matter of Islamic and national law, nor were they aware of what particular stipulations they were allowed to include. ${ }^{59}$ A group of women under the heading of the Communication Group for the Enhancement of the Status of Women in Egypt formulated a draft marriage contract that not only contained a blank space for stipulations but also included nine questions that the marriage notary was supposed to ask the couple (and the man in particular), and the answers would become part of the marriage contract. The questions included: "Do you agree to abstain from marrying an additional wife, and if you do so marry, that your wife will have the right to divorce herself?",60 and "Do you

\footnotetext{
59 Zulficar, "The Islamic Marriage Contract in Egypt," 239.

${ }^{60}$ This kind of provision is known as a delegated divorce because the husband delegates to the wife his right of repudiation in specific circumstances. In the absence of this condition, if the husband takes a
} 
agree that your wife will complete her higher academic studies?" By posing the questions to the husband and requiring him to give a "yes" or "no" reply, the proponents of this type of contract intended to force the couple to have a conversation about their marital life, at least by the moment that they were entering into their marriage, with the hopes that the husband would agree to these conditions that would then become part of the marriage contract.

The Egyptian government adopted the new marriage contract project and sought to obtain the opinions of religious scholars. ${ }^{61}$ The Shaykh of al-Azhar, one of the two highest state religious official in Egypt, rejected the proposed contract on the grounds that while such a delegated repudiation (in the case of polygamy) was lawful according to some Sunni schools of law, it should be made as a private agreement between the parties, and not put into the standard marriage contract. His reason was that such a provision violated the Quranic concept of man's superiority over women (the notion of qawwama), as stated in Q 4:34: "men shall take full care of women with the bounties which God has bestowed more abundantly on the former than on the latter, and with what they may spend out of their possessions. And the righteous women are the truly devout ones, who guard the intimacy which God has [ordained to be] guarded."62 This argument is essentially a rejection of the reform strategy of "encouraging the permissible"; the stipulation itself is permissible, he concluded, but encouraging it is not. He seems to assume that even suggesting it to couples violates the man's qawwama.

The strategy of requiring the permissible imposes an Islamically permissible

second wife, the first wife's options are to give up financial rights in a khul divorce or to claim that she is harmed by her husband's polygamous marriage and attempt to get a judicial divorce for harm.

${ }^{61}$ Shaham, "State, Feminists and Islamists: The Debate over Stipulations in Marriage Contracts in Egypt," 466.

${ }^{62}$ Ibid., 472. 
action on a party, either unilaterally or in the course of a contractual exchange. While it may seem functionally similar, this strategy is distinct from a national law that directly requires individuals to behave in a particular way, and it is employed in order to bypass the expected opposition that would arise from the imposition of such a direct requirement.

This strategy has been used in several countries to protect the rights of grandchildren who would otherwise be prevented according to Islamic inheritance rules from inheriting from their grandparents in certain contexts. Islamic inheritance law provides detailed rules for the distribution of assets to specified classes or heirs in specified percentages and, at least for $2 / 3$ of one's estate, the rules are mandatory. An individual may dispose of the remaining $1 / 3$ of his or her estate in a testamentary bequest, subject to certain limitations. The problem arises because a grandchild is not entitled to a share of a grandparent's estate when the parent (that is, the child of the deceased grandparent) predeceased the grandparent. If the grandchild's parent had been alive, the grandchild would have been entitled to some share of the grandparent's estate. This was seen as an unfair result that needed modification. Egypt, as well as several other countries, now requires individuals with orphaned grandchildren to bequest to each such grandchild the amount that the predeceased child would have received had the parent still been alive, provided that it in total does not exceed the discretionary $1 / 3$ amount. If the grandparent does not do so, this will be imposed upon the estate. ${ }^{63}$ If the deceased had already identified in her will other individuals who were to receive this discretionary $1 / 3$ share, the orphaned grandchildren's share of the 1/3 takes priority over those others. This

\footnotetext{
${ }^{63}$ Esposito and Delong-Bas, Women in Muslim Family Law, 64-65. This is slightly more complicated by a gender issue - in some cases, this only applies when claiming inheritance from a predeceased father.
} 
strategy was considered necessary in order to address a serious problem of orphaned grandchildren without actually modifying the required distribution of shares for that $2 / 3$ portion of the estate as a matter of Islamic law. ${ }^{64}$

A similar approach has been used to benefit kafala children in Morocco and other countries. As discussed above under the strategy of limitation of conceptual jurisdiction, the kafala process does not result in the child receiving from the kafala parent all of the rights of a biological child. Specifically, the child remains the heir of his or her biological parents (which has little practical effect if the parents are unknown), and does not inherit from the kafala parent according to the Islamic system of inheritance. The child's only possibility of inheritance is a bequest from the discretionary $1 / 3$ if the parents so provide it. Due to the problem of kafala parents failing to so provide for the kafala children, Morocco now requires as a matter of practice that the parents create a will as part of the kafala process bequeathing this discretionary $1 / 3$ of their estate to the kafala child. ${ }^{65}$ Judges will not sign the child's permanent abandonment order, a document required in order to legally processing the kafala child, unless the parents provide for this bequest. $^{66}$ The result is to provide the child some support upon the death of the parents without changing the Islamic rules of inheritance that govern the $2 / 3$ portion of the estate.

\section{$\underline{\text { I. Return to Pre-Reform Status }}$}

In some situations, a reform tries to change entrenched social practices too

\footnotetext{
${ }^{64}$ Egyptians such as Nasr Abu Zayd who have suggested that the Islamic inheritance divisions (including the inequality between men and women) be modified directly to take into account present social need have been roundly criticized.

${ }^{65}$ Essebah interview.

66 Ibid.
} 
quickly. Some of the strategies that have been discussed can produce negative effects for women and children if the parties do not comply with the new law. This is particularly true when matters are removed from the jurisdiction of the judiciary, which can result in a woman's inability to seek judicial divorce for harm or sue for maintenance if, for example, she is underage at the time she seeks the court's assistance. The reform of the reform is thus a retreat that recognizes and affirms as applicable the rules of classical Islamic law that the initial reform had tried to move away from.

This strategy has been used in Egypt to partly remedy the consequences of the marriage registration laws. In most Muslim-majority countries, early reform efforts included marriage registration requirements. These requirements did not attempt to change the substance of how parties married under Islamic law, but rather merely required that a couple register their marriage with an official marriage notary and complete a form marriage contract produced by the state. In Islamic law, however, no such contract or procedure is necessary to conclude a marriage, which is a private contractual agreement concluded between a husband and wife in the presence of two witnesses. Traditionally, this was an oral agreement, and while marriage contracts could be put into writing, the absence of a document did not affect the marriage's validity as a religious matter.

To encourage couples to register their marriages, the limitation of judicial jurisdiction strategy was used, such that according to a 1931 law a judge was precluded from hearing a claim relating to a marriage that had not been registered when one party denied the existence of the marriage. ${ }^{67}$ If both parties recognized the marriage, the judge did not look into its legal basis, but if a woman sought to compel her husband to pay her

${ }^{67}$ Art. 17. 
maintenance, for example, and he denied the marriage and it had not been registered, the marriage simply did not exist as a matter of national law and the judge had no power to hear her claim. In Egypt, marriages that are not registered are commonly referred to as 'urfi, or customary, marriages. ${ }^{68}$

Despite the use of the limitation of jurisdiction strategy to provide an incentive to register marriages, many couples still enter into 'urfi marriages for a wide range of reasons. Couples below the specified age have 'urfi marriages insofar as they comply with the Islamic marriage requirements but cannot register their marriage due to their ages. 'Urfi marriages have become popular among college students who do not intend permanent marriages (although an 'urfi marriage is explicitly not a temporary marriage, something impermissible in Sunni Islam) but want to engage in sexual relations without committing the sin of extra-marital sex. A woman might enter into an 'urfi marriage so that she does not lose custody of her children from a previous marriage or does not lose the pension of her deceased husband, which could happen if the marriage is registered and thus known by the authorities. When entering into a polygamous marriage, some men use 'urfi marriages in order to avoid the notification to the first wife that would take place if the second marriage was registered.

One major problem with the non-recognition of 'urfi marriages became the inability of women to turn to the courts for divorce. Unless the husband repudiated the wife or agreed to divorce by mutual consent, the wife had no ability to get a divorce since the other options, the new judicially enforced mutual consent and divorce on the grounds

\footnotetext{
${ }^{68}$ Not all urfi marriages are concluded in a way that complies with the Islamic requirements for marriage, however. The two witnesses may be missing or the couple may fail to publicize the marriage in an effort to keep it a secret, such as when young people marry without their parents' knowledge (presumably because the parents would object).
} 
of harm, require a judge to hear the claim, which was unavailable if the husband denied the marriage. Because the husband would potentially have to pay some temporary maintenance to the wife and child support, some men denied their 'urfi marriages to a judge, putting the women and children in a very difficult situation. Under Law 1 of 2000, the limitation of judicial jurisdiction clause of the 1931 law was modified to add that in claims of divorce or dissolution, the judge may heard the claim even if the party sued denies the marriage if the marriage can be proven by any documentary evidence. ${ }^{69}$ This new rule gives the wife a chance of proving her 'urfi marriage and thus getting access to the courts if some kind of informal written marriage agreement exists and the wife can get access to it. This step does not solve the entire problem of 'urfi marriages, however, since this still leaves a vast number of marriages that were entered into with the requirements of an Islamic marriage but yet no document proving it exists (or is accessible to the woman) at the time she seeks the help of the court. ${ }^{70}$

The goal of the reformers was to allow some women in 'urfi marriages to seek judicial relief without substantially undermining the long-standing national requirement of marriage registration. The registration process not only allows the state to perform a basic function of knowing the marital status of its citizens (which is related to issues of paternity and inheritance) but also serves as an important means of carrying out reform goals in its own right. Marriage notaries are not supposed to register couples when one of them is under the specified minimum age, for example, and so any loosening of the registration requirement, as in Law 1 of 2000, could have the consequences of undermining other reform goals.

\footnotetext{
${ }^{69}$ Law No. 1 of 2000.

${ }^{70}$ In some cases, the wife alleges that the husband destroyed the document once he learned that she was going to seek a judicial divorce.
} 


\section{$\underline{\text { Conclusion }}$}

In an effort to improve the rights of women and children, reformers and legislators have pursued what we have called an internal approach, in the sense that legal changes are presented as compliant with Islamic law. In this project, we are not concerned with evaluating the validity of this compliance claim, but rather our interest is on the tangible outcomes of the reforms. By identifying and examining these strategies, our goal is to facilitate impact studies that take into consideration the type of strategy used to help better determine what approaches are the most effective. Reforms that rely on exercising preference may be well accepted, for example, but there is a limit to how far this strategy can go since it relies on pre-existing opinions. Reinterpreting a source text might allow for more creativity, but it also might lead to more vocal criticism depending on how that reinterpretation is done. And other strategies might cause unintended consequences that have to be addressed by further reforms. Ultimately, our goal is to achieve the best possible legal results for women and children, and so this article is intended to provoke discussions not only about the effectiveness of various internal strategies but also the comparative strengths and weaknesses of internal approaches alongside others, such as those driven by universal human rights norms. 